\title{
Effects of mistletoe infestation on the decline and mortality of Abies cephalonica in Greece
}

\author{
Y. Raftoyannis, K. Radoglou, M. Bredemeier
}

Raftoyannis Y., Radoglou K., Bredemeier M., 2015. Effects of mistletoe infestation on the decline and mortality of Abies cephalonica in Greece . Ann. For. Res. 58(1): 55-65.

\begin{abstract}
In recent decades, stands of Greek fir (Abies cephalonica Loudon) are declining and high tree mortality has been observed in some years. The exact causes of fir decline and mortality have not been established although many have been proposed (drought, climatic change, air pollution and attacks by pathogens or insects). This study has focused on the effects of mistletoe (Viscum album L.) on fir crown condition by assessing the mistletoe infestation level and its effects on fir defoliation. In the fir forests of Central Greece, the tree crown condition and the extent of mistletoe infestation were assessed and their relationships with tree height, altitude and aspect were investigated. The role of mistletoe on overall fir mortality was investigated by assessing standing trees that had died recently. The leaf water potential and chlorophyll fluorescence of mistletoe and fir were also measured during one growth season. The results showed that mistletoe infestation is related to crown defoliation. Altitude and tree height were not related with mistletoe infestation while infestation levels were lower on northern exposures. Mistletoe showed significantly lower water potentials and higher photochemical efficiencies than fir branches. Keywords Viscum album, Abies cephalonica, crown condition, water potential.
\end{abstract}

Authors. Yannis Raftoyannis (rafto@teilam.gr) - Department of Forestry, Central Greece University of Applied Sciences, 36100 Karpenisi, Greece; Kalliopi Radoglou - Department of Forestry and Management of Environment and Natural Resources, Democritus University of Thrace, 68200 Orestiada, Greece; Michael Bredemeier - Forest Ecosystems Research, Center for Biodiversity and Sustainable Land Use (CBL), University of Göttingen, Büsgenweg 2, 37077 Göttingen, Germany.

Manuscript received December 06, 2014; revised March 04, 2015; accepted March 12, 2015; online first March 16, 2015.

\section{Introduction}

Greek fir (Abies cephalonica Loudon) is widely distributed mainly in the mountains of central and southern Greece, more often at altitudes ranging between $800-1800 \mathrm{~m}$. In recent dec- 
ades, episodes of increased stand decline and mortality have been observed and a number of possible causes have been proposed such as drought, air pollution, plant parasites, pests and pathogens (Heliotis et al. 1988, Raftoyannis \& Radoglou 2001, Tsopelas et al. 2004, Economou et al. 2007, Raftoyannis et al. 2008).

One of these studies reported a strong relationship between mistletoe infestation and tree mortality and concluded that mistletoe is the most important biotic factor of tree decline and mortality (Tsopelas et al. 2004). The adverse effects of mistletoe infection on Abies alba stands have been reported in many European countries (Noetzli et al. 2003, Idžojtić et al. 2008, Barbu 2009; Barbu 2010;,Oliva \& Colinas 2010, Diminić et al. 2011, SangüesaBarredaa et al. 2013). Mistletoe infestation is also high in the inner Alpine valleys and contributes to the loss of Pinus sylvestris in these areas (Dobbertin et al. 2005, Dobbertin \& Rigling 2006, Rigling et al. 2010).

The European mistletoe is an evergreen semi-parasitic shrub, growing on different woody hosts. Based on host specificity, three host races are distinguished in Europe: $V$. album subsp. album L. on dicotyledonous trees, $V$. album subsp. abietis (Wiesb.) Abromeit on Abies species, and $V$. album subsp. austriacum (Wiesb.) Vollmann mainly on Pinus species. Viscum album is dioecious, insect pollinated and has fleshy fruits that are dispersed by birds (Zuber 2004). The first symptom of mistletoe infection is localized hypertrophy of host tissue at the site of infection. Later, branch dieback is observed and dead tops are common symptoms of severely infected trees due to the diversion of resources to the mistletoes. Mistletoe infection results in reduction of growth, vigour and seed production. Severely infected trees are often predisposed to secondary infections by various pests and diseases which often contribute to the death of the mistletoe-infected plants (Mathiasen et al. 2008).

Mistletoe infection progresses slowly and usually takes several years to reach the point where host growth and reproduction are adversely affected from an economic perspective. In North America, the economic losses from dwarf mistletoes (Arceuthobium spp.) amount to billions of dollars annually (Geils \& Hawksworth 2002).

Mistletoe infection does not directly lead to tree death but its presence in a tree increases the impact of drought and strongly reduces its capability to assimilate carbon under dry conditions. Trees with mistletoes have a leak in their water flow and storage system and the only way to survive is to reduce their transpiration by closing their stomata (Zweifel et al. 2012). This is probably a successful mechanism against tree death from hydraulic failure in the short term but increases the risk of carbon starvation and death in the long term (Zweifel et al. 2012).

Viscum album is able to photosynthesize but uses the xylem and phloem sap of its host as a source of carbon, nitrogen and sulphur for growth and development (Escher et al. 2008). Nutrient uptake of the mistletoe requires a high amount of water and thus increases the water stress in host trees (Calder \& Bernhardt 1983). $\mathrm{CO}_{2}$ net uptake is usually lower in mistletoes than in their hosts and mistletoe infections may disrupt the host stomatal control system, causing early and oscillating closure of host stomata, thereby diminishing host's photosynthetic gain (Popp \& Richter 1998, Glatzel \& Geils 2009).

The objective of this study was to quantify the effect of mistletoe infestation on Greek fir crown condition and mortality. To achieve this objective many variables such as tree height, mistletoe incidence and infestation level and crown defoliation were recorded. The present study is also a first attempt to investigate the physiological influence of $V$. album subsp. abietis parasitism on $A$. cephalonica. The leaf water potential and chlorophyll fluorescence of mistletoe and its host were measured as indicators of water stress and photosynthetic capacity. 


\section{Materials and methods}

\section{Mistletoe infestation and crown condition}

This study was conducted in the mountain forests of Central Greece in 2013. In this area, the forests are usually dominated by Greek fir with an understory mainly composed of Quercus coccifera L., Quercus frainetto Ten. and Juniperus oxycedrus L. These forests are not managed intensively, only selective cutting is allowed and their regeneration is natural. Soils are mainly luvizols, alisols and acrisols developed on limestone and sandy flysch. The area has a continental Mediterranean climate, with mean annual air temperature of $10.8^{\circ} \mathrm{C}$ and mean annual rainfall of $1114 \mathrm{~mm}$. The dry season lasts on average 2.5 months, from midJune to the end of August.

In the first stage of the field study, the tree crown condition and the extent of mistletoe infestation were assessed by allocating 15 sampling plots of 100 trees each (total 1500 trees) in a wide area in the mountains of Central Greece (Table 1). The centres of sampling plots were randomly selected from satellite images of Google Earth, and then were located on site with the help of the images and a GPS. At the sampling point, the same observer assessed the nearest 100 trees. Only predominant, dominant and co-dominant trees, over 10 $\mathrm{m}$ in height, were considered because dominated, suppressed and young trees were usually not infected.

The mistletoe infestation rate of fir trees was assessed using four classes: 0 - no visible mistletoe, 1 - low mistletoe infestation with at least one mistletoe bush, 2 - medium mistletoe infestation with several mistletoe bushes, 3 - heavy mistletoe infestation with many mistletoe bushes on at least one-third or more of the branches in the tree crown (Dobbertin \& Rigling 2006). Then, a mean infestation rate for each plot was calculated by multiplying the number of trees in each infestation class by the class value. Crown condition was assessed as a percentage of defoliation in comparison with a fully foliated local reference tree and following the methods suggested by Muller \& Stierlin (1990) and Eichhorn et al. (2010). Defoliation rates were estimated in $10 \%$ classes from $0 \%$ to $100 \%$, where $0 \%$ means fully foliated and $100 \%$ means a dead host tree. In addition, the height of each tree was measured using a laser hypsometer (LaserAce, MDL, UK).

Table 1 Location, coordinates, altitude and main aspect of sampling plots of the first field study

\begin{tabular}{llcl}
\hline Location & Coordinates & Altitude (m.a.s.1.) & Main aspect \\
\hline Abliani & $38.752753 \mathrm{~N}, 21.896516 \mathrm{E}$ & 1476 & South \\
Agrafa & $39.149081 \mathrm{~N}, 21.632103 \mathrm{E}$ & 1123 & South \\
Artotina & $38.709169 \mathrm{~N}, 22.028231 \mathrm{E}$ & 1183 & North \\
Chalkiopoulo & $38.980310 \mathrm{~N}, 21.393676 \mathrm{E}$ & 921 & South \\
Domnista & $38.745752 \mathrm{~N}, 21.836584 \mathrm{E}$ & 1255 & West \\
Fourna & $39.052465 \mathrm{~N}, 21.888595 \mathrm{E}$ & 1134 & West \\
Gardiki & $38.831968 \mathrm{~N}, 21.969203 \mathrm{E}$ & 1102 & East \\
Granitsa & $39.109629 \mathrm{~N}, 21.515072 \mathrm{E}$ & 802 & East \\
Karpenisi & $38.890478 \mathrm{~N}, 21.803486 \mathrm{E}$ & 891 & North \\
Klitso & $39.113480 \mathrm{~N}, 21.817748 \mathrm{E}$ & 1144 & East \\
Mavromata & $39.058438 \mathrm{~N}, 21.735732 \mathrm{E}$ & 946 & North \\
Neohori & $38.795327 \mathrm{~N}, 22.194376 \mathrm{E}$ & 1209 & North \\
Platanos & $38.625757 \mathrm{~N}, 21.828881 \mathrm{E}$ & 1150 & South \\
Sarkini & $38.795862 \mathrm{~N}, 21.634348 \mathrm{E}$ & 864 & East \\
Trovato & $39.211281 \mathrm{~N}, 21.604935 \mathrm{E}$ & 1131 & East \\
\hline
\end{tabular}


A second field study investigated the effects of altitude and exposure on mistletoe infestation by allocating sampling plots at 7 altitude thresholds $(900,1000,1100,1200$, $1300,1400,1500 \mathrm{~m}$ ) for each of the 4 main exposures (north, east, south, west), on Mount Tymfristos (38.943840 N, 21.823407 E). Each sampling plot included 100 fir trees resulting in a total of 2800 trees studied. The mistletoe infestation rate of each tree was recorded and then a mean infestation rate for each plot was calculated. Sampling and assessment methods were as in the first stage of the study.

In a third study stage, the role of mistletoe on overall fir mortality was investigated by observing 1216 standing trees that had died recently, for mistletoe infestation symptoms such as dead mistletoe bushes, branch and stem swellings, deformed crown tops, etc. A dead fir tree that was heavily infested with mistletoe when alive could be easily distinguished from a dead fir tree with low or no mistletoe infection where a symmetrical crown with no deformations could be observed. The assessed dead trees were identified and located during the field trips of the first and second study stages, outside or inside the sampling plots. The percentage of trees that showed symptoms of mistletoe infection was calculated out of the total 1216 dead trees encountered in our survey.

\section{Physiological study}

This stage of the study was conducted in 2012, from June to October, in an uneven aged fir stand $(38.741526 \mathrm{~N}, 21.686101 \mathrm{E}, 1144 \mathrm{~m}$ a.s.1.). The soil was mainly calcareous with an average depth of 30-50 cm. From May to October 2012, air temperature and rainfall were recorded on site, using a portable meteorological station (Hobo H8 Pro, Onset Computer Corporation, USA).

In order to assess the effect of mistletoe infection on fir physiology, we collected data on leaf water potential and chlorophyll fluorescence. One fir tree of a height of $13 \mathrm{~m}$ and diameter at breast height of $42 \mathrm{~cm}$ was selected. This tree was moderately infected with several mistletoe bushes in the crown (infestation class 2), and a defoliation rate of $30 \%$. Measurements were made on terminal twigs of one infected fir branch and its mistletoe plant and one neighbouring uninfected fir branch. Branches were located at the lower part of fir crown and the mean crown diameter of the mistletoe bush was $55 \mathrm{~cm}$.

Plant water stress was assessed by measuring the midday leaf water potential once per month $(21 / 6,17 / 7,21 / 8,17 / 9,22 / 10)$, between $11 \mathrm{am}$ and $2 \mathrm{pm}$, on 3 leaves of mistletoe and 3 fir needles, using a Scholander-type pressure chamber (SKPM 1400, Skye Instruments Limited). Chlorophyll fluorescence has been widely used to document the effects of numerous biotic and abiotic stresses on plants and the maximum photochemical efficiency $(\mathrm{Fv} / \mathrm{Fm})$ is the most widely used fluorescence test parameter for plant stress detection (Maxwell \& Johnson 2000). The maximum photochemical efficiency $(\mathrm{Fv} / \mathrm{Fm})$ of the mistletoe and the fir was measured on 10 different days $(21 / 6,17 / 7$, 24/7, 31/7, 21/8, 28/8, 13/9, 17/9, 1/10, 22/10), between 11 am and $2 \mathrm{pm}$. Fir needles and mistletoe leaves were covered with a black cotton bag and kept in darkness for $30 \mathrm{~min}$. Then the minimal (Fo) and maximal (Fm) fluorescence were measured and the maximum quantum yield of photosystem II (Fv/Fm) was calculated as $\mathrm{Fv} / \mathrm{Fm}=(\mathrm{Fm}-\mathrm{Fo}) / \mathrm{Fm}$ as described by Maxwell and Johnson (2000). Chlorophyll fluorescence data were obtained using a portable chlorophyll fluorometer (OS-30p, OptiSciences Inc.) on 10 needles and mistletoe leaves.

\section{Data analyses}

Correlation analysis was used to explore the relationships among tree height, mistletoe infestation rate and defoliation. Analysis of variance (ANOVA) was applied after an arcsinesquare-root transformation of the defoliation 
variable and treating mistletoe infestation rate as a nominal variable. ANOVA was also used to analyse the leaf water potential and chlorophyll fluorescence data between mistletoe and fir. Subsequently, means were compared with Tukey's multiple comparisons test. Analyses were conducted at a significance level $p<$ 0.05 .

\section{Results}

\section{Mistletoe infestation and crown condition}

The assessment of fir crown condition showed that $66 \%$ of trees exhibited zero or slight defoliation $(0-20 \%), 24 \%$ moderate defoliation $(30-50 \%)$ and $10 \%$ severe defoliation (60$90 \%$ ) (Table 2). Data analysis from 1500 sampled trees showed that mistletoe infestation and fir defoliation rates were highly related $(r$ $=0.884, p=0.000)$. No meaningful relationship could be detected between tree height and mistletoe infestation $(r=0.047, p=0.069)$ or defoliation rate $(r=0.034, p=0.192)$.

Crown assessments revealed that $59 \%$ of fir trees were infected with mistletoe (Table 3). Low infestation rates were recorded for $32 \%$ of trees, medium infestation for $19 \%$ and severe infestation for $8 \%$ of the trees. Trees with no mistletoe infection showed an average defoliation rate of $6 \%$. Trees with low mistletoe infestation showed on average $18 \%$ defoliation. Trees with medium mistletoe infestation, showed a mean $43 \%$ crown loss. Trees with heavy mistletoe infestation showed a severe $70 \%$ mean defoliation. Differences in defoliation among infestation classes were always significant.

In the second study stage, data from 2800 trees, showed that the highest mistletoe infestation was observed on the southern exposure followed by the western and eastern exposures (Figure 1). Mistletoe infestation on northern exposures was almost half of the other exposures. No clear effect of altitude on mistletoe infestation rate could be distinguished for all mountain exposures.

The results of the third stage of the field study revealed that from 1216 observed standing dead trees, only 237 (19\%) showed clear symptoms of severe mistletoe infection prior to death.

Table 2 Crown condition of fir trees allocated in defoliation classes. Percentages were rounded to the closest whole number

\begin{tabular}{lll}
\hline Defoliation $(\%)$ & Number of trees & Percentage of trees $(\%)$ \\
\hline $0-20$ & 1000 & 66 \\
$30-50$ & 359 & 24 \\
$60-90$ & 141 & 10 \\
\hline
\end{tabular}

Table 3 Mistletoe infestation rate and mean percentage of defoliation of fir trees. $\mathrm{N}$ indicates the number of observations for each mistletoe infection class. Different letters indicate significant $(P<0.05)$ differences in defoliation among mistletoe infection classes. Percentages were rounded to the closest whole number

\begin{tabular}{llll}
\hline Mistletoe infestation class & Number of trees & Percentage of trees (\%) & Defoliation (\%) \\
\hline 0 & 622 & 41 & $6^{\mathrm{a}}$ \\
1 & 487 & 32 & $18^{\mathrm{b}}$ \\
2 & 278 & 19 & $43^{\mathrm{c}}$ \\
3 & 113 & 8 & $70^{\mathrm{d}}$ \\
\hline
\end{tabular}




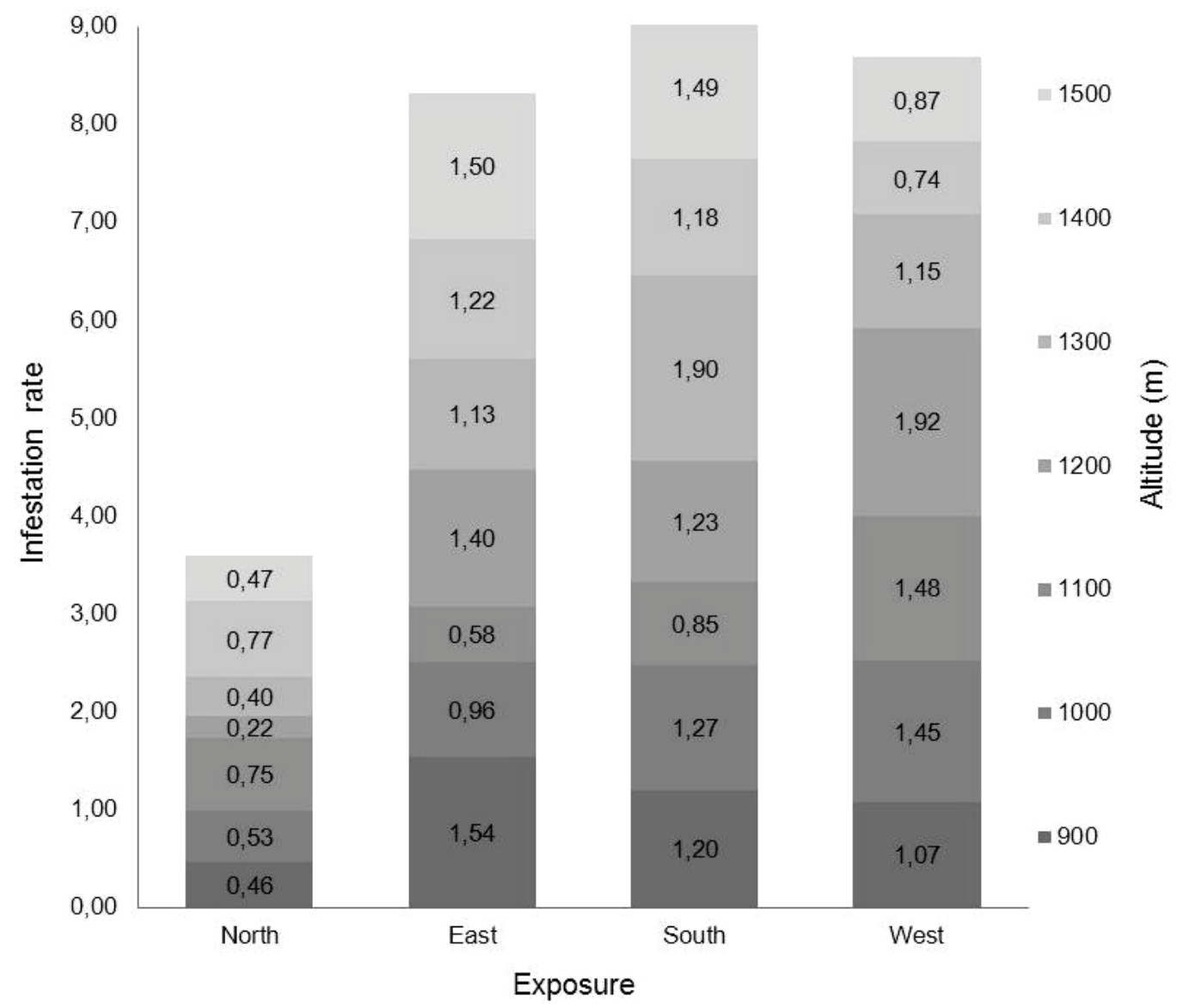

Figure 1 Mistletoe infestation at different altitudes and exposures. Values represent mean infestation rates for each exposure and altitude combination

\section{Physiological study}

In the study area, mean daily air temperature increased from around $15^{\circ} \mathrm{C}$ to $25^{\circ} \mathrm{C}$ from mid-June and dropped to $15^{\circ} \mathrm{C}$ around midSeptember (Figure 2). May was a rainy month but June and July were very dry months. Some high rainfall events occurred at the beginning of August and the middle of September but the main wet period started after the middle of October.

During the whole observation period, the midday leaf water potential ( $\left.\Psi_{\text {leaf }}\right)$ of the mistletoe was significantly lower than the $\Psi_{\text {leaf }}$ of infected and uninfected branches (Table 4). The $\Psi_{\text {leaf }}$ of infected fir branches was significantly lower than uninfected ones in July, August and September but not in June and Octo- ber. The $\Psi_{\text {leaf }}$ of the mistletoe and of the fir tree decreased from June to August, when water availability was lower, and then increased up to October.

The maximum photochemical efficiency (Fv/Fm) of the mistletoe and fir leaves decreased mainly in July and August and then recovered (Table 5). Fv/Fm was always significantly lower in mistletoe leaves than in fir needles. Fv/Fm of needles from infected and uninfected branches was similar and significant differences were found only for dates at the end of August. The range of mean $\mathrm{Fv} / \mathrm{Fm}$ in fir needles was from 0.66 to 0.80 and in mistletoe from 0.54 to 0.71 . 


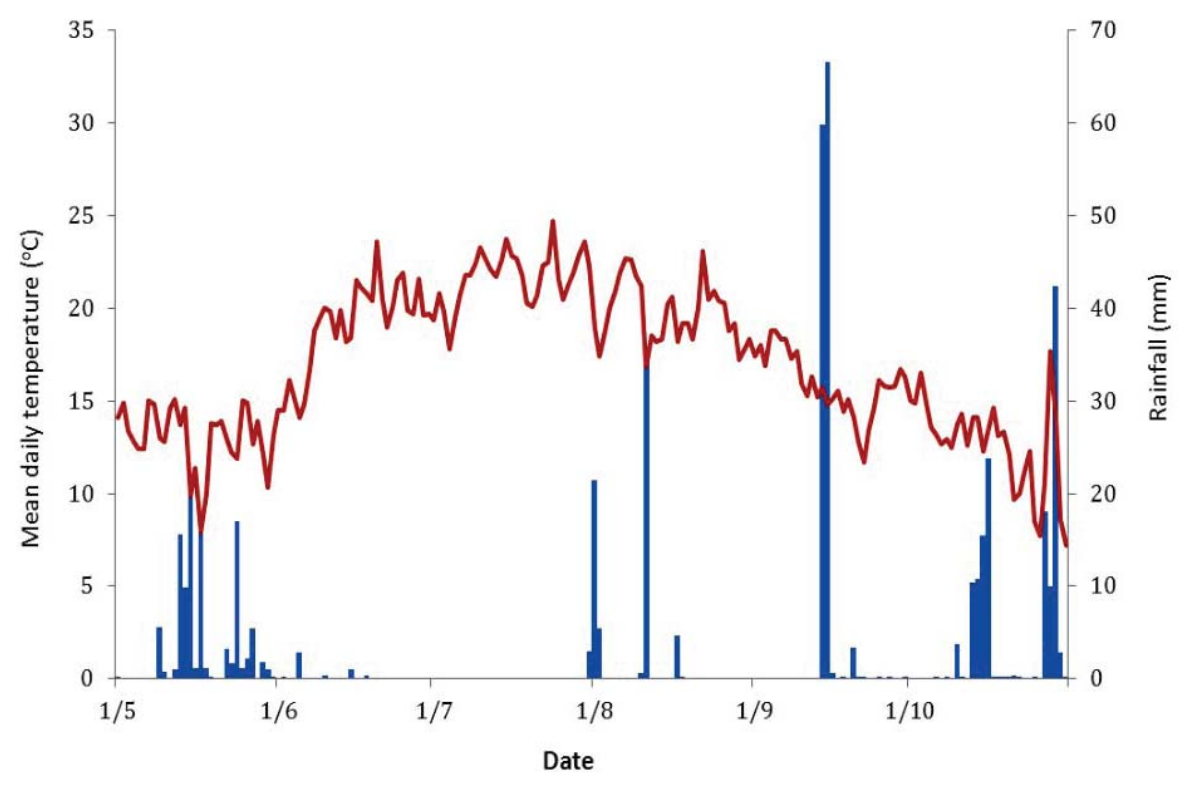

Figure 2 Mean daily temperature and rainfall from May to October 2012

Table 4 Midday leaf water potential of mistletoe and infected or uninfected branches of fir trees. The mean values of 3 observations are expressed in MPa. Different letters indicate significant $(P<0.05)$ differences among mistletoe and infected or uninfected branches for the same day

\begin{tabular}{llll}
\hline Observation date & Mistletoe & Infected branch & Uninfected branch \\
\hline $21 / 6$ & $-1,94^{\mathrm{a}}$ & $-1,13^{\mathrm{b}}$ & $-1,03^{\mathrm{b}}$ \\
$17 / 7$ & $-2,75^{\mathrm{a}}$ & $-1,91^{\mathrm{b}}$ & $-1,59^{\mathrm{c}}$ \\
$21 / 8$ & $-3,10^{\mathrm{a}}$ & $-2,17^{\mathrm{b}}$ & $-1,87^{\mathrm{c}}$ \\
$17 / 9$ & $-2,60^{\mathrm{a}}$ & $-1,52^{\mathrm{b}}$ & $-1,20^{\mathrm{c}}$ \\
$22 / 10$ & $-2,10^{\mathrm{a}}$ & $-1,21^{\mathrm{b}}$ & $-1,06^{\mathrm{b}}$ \\
\hline
\end{tabular}

Table 5 Maximal photochemical efficiency $(\mathrm{Fv} / \mathrm{Fm})$ of mistletoe and infected or uninfected branches of fir trees. Values are means of 10 observations. Different letters indicate significant $(P<0.05)$ differences among mistletoe and infected or uninfected branches for the same day

\begin{tabular}{llll}
\hline Observation date & Mistletoe & Infected branch & Unifected branch \\
\hline $21 / 6$ & $0,70^{\mathrm{a}}$ & $0,79^{\mathrm{b}}$ & $0,80^{\mathrm{b}}$ \\
$17 / 7$ & $0,63^{\mathrm{a}}$ & $0,72^{\mathrm{b}}$ & $0,72^{\mathrm{b}}$ \\
$24 / 7$ & $0,58^{\mathrm{a}}$ & $0,66^{\mathrm{b}}$ & $0,68^{\mathrm{b}}$ \\
$31 / 7$ & $0,54^{\mathrm{a}}$ & $0,66^{\mathrm{b}}$ & $0,67^{\mathrm{b}}$ \\
$21 / 8$ & $0,57^{\mathrm{a}}$ & $0,70^{\mathrm{b}}$ & $0,79^{\mathrm{c}}$ \\
$28 / 8$ & $0,64^{\mathrm{a}}$ & $0,75^{\mathrm{b}}$ & $0,79^{\mathrm{c}}$ \\
$13 / 9$ & $0,65^{\mathrm{a}}$ & $0,78^{\mathrm{b}}$ & $0,79^{\mathrm{b}}$ \\
$17 / 9$ & $0,68^{\mathrm{a}}$ & $0,80^{\mathrm{b}}$ & $0,80^{\mathrm{b}}$ \\
$1 / 10$ & $0,71^{\mathrm{a}}$ & $0,79^{\mathrm{b}}$ & $0,80^{\mathrm{b}}$ \\
$22 / 10$ & $0,69^{\mathrm{a}}$ & $0,78^{\mathrm{b}}$ & $0,78^{\mathrm{b}}$ \\
\hline
\end{tabular}




\section{Discussion}

In this study, $59 \%$ of the fir trees were infected by mistletoe which is lower than the $68 \%$ reported for a drier site (Tsopelas et al. 2004). Almost $25 \%$ of the trees showed moderate degrees of defoliation compared to almost half of fir trees in the drier site, while about $10 \%$ of the trees were severely damaged in both studies (Tsopelas et al. 2001, Tsopelas et al. 2004). Moreover, the percentages of trees, in each mistletoe infection class, are comparable with a previous study (Tsopelas et al. 2004). However, the observed level of mistletoe infestation is higher when compared to other reported values for European $A$. alba forests. The incidence of mistletoe was $14 \%$ in Spain (Oliva \& Colinas 2007), 22\% in Romania (Barbu 2009) and $30 \%$ in Croatia (Idžojtić et al. 2008). It seems that the environmental conditions and forest management methods in Greece favour mistletoe spread.

The intensity of mistletoe infestation was positively related to crown defoliation, a relationship that has also been observed for $A$. alba (Oliva \& Colinas 2007, Diminić et al. 2011). Mistletoe infection induces a reduction in needle length and increases needle shed of fir trees with a subsequent decrease in primary production and carbohydrate availability (Rigling et al. 2010, Barbu 2012). A high degree of mistletoe attack has therefore a negative effect on tree growth (Noetzli et al. 2003, Barbu 2010, Catal \& Carus 2011) and increases the sensitivity of trees to drought to a point that even the rising atmospheric $\mathrm{CO}_{2}$ concentrations cannot compensate for these negative effects (Sangüesa-Barreda et al. 2012, SangüesaBarredaa et al. 2013).

Mistletoe infection can be considered as both a predisposing factor for tree death, by increasing needle loss following drought, and a contributing factor by increasing the level of water stress during drought. Usually, a strong correlation between fir mortality and mistletoe infestation rate is observed (Tsopelas et al.
2004, Dobbertin \& Rigling 2006, Idžojtić et al. 2008, Oliva \& Colinas 2010). In our study, we did not monitor the effect of mistletoe on tree mortality over a long period, but we found that mistletoe could be considered as a major contributing factor responsible for the death of almost one fifth $(19 \%)$ of the recorded dead trees.

Mistletoe, usually, infects and damages dominant and older trees of A. alba (Noetzli 2003, Barbu 2009, Oliva \& Colinas 2010). Assessed trees ranged from 10 to $28 \mathrm{~m}$ in height and no relationship between tree height and mistletoe infestation or defoliation level was found. It seems that dominant trees over $10 \mathrm{~m}$ in height have similar probabilities of mistletoe infestation. The removal of dominant and older infested trees and the shortening of felling cycles could reduce mistletoe incidence although the increased light conditions after thinning may favour mistletoe spread and growth due to increased bird activity (Mathiasen et al. 2008).

Altitude has an apparent influence on mistletoe spread because temperature is an essential factor for its growth (Plagnat 1950) and a negative correlation between elevation and mistletoe incidence is usually observed (Idžojtić et al. 2008, Barbu 2009, Barbu 2010). This relationship can be so close that the upward spread of mistletoe infestation has been proposed as a good indicator of the ongoing increase in winter temperatures (Dobbertin et al. 2005). However, we found that mistletoe occurrence and infestation rate were not affected by altitude. This result could be possibly explained due to the higher mean annual temperatures in Greek mountains compared to previous reports from colder environments. It seems that in Central Greece, air temperature is not a limiting factor for mistletoe growth and spread, even in the higher altitudes.

Light plays an important role in mistletoe growth and is related to high mistletoe incidence and infestation rates in southern exposures and open stands (Idžojtić et al. 2008, Barbu 2009, Barbu 2010, Oliva \& Colinas 
2010). We found significantly lower rates of mistletoe infestation on fir stands located on northern exposures compared to other expositions. Less light and lower temperatures could explain this observation because mistletoe is a light-demanding species, especially for seed germination (Zuber 2008).

In the case of $A$. cephalonica, the occurrence of annual growth usually before the dry summer period and the high water-use efficiency could help trees to avoid water stress (Aussenac 2002). However, drought stress enlarges the negative effects of mistletoes on tree water relations. A mistletoe infestation level that might be tolerated by a tree at moderate climatic conditions could turn out lethal under intense drought stress (Rebetez \& Dobbertin 2004). As a result, after drought, significantly increased mortality rates of host trees are observed especially in xeric sites (Rigling et al. 2010).

Our results support the common observation that mistletoes show lower leaf water potentials than their hosts. Similar results have been reported for $V$. album (Zweifel et al. 2012) and other mistletoes like Loranthus europaeus Jacq. (Glatzel 1983), Phoradendron juniperinum Engelm. ex A. Gray (Ehleringer et al. 1986), Amyema linophyllum (Fenzl) Tieghem (Davidson et al. 1989) and Pthirusa maritima (Goldstein et al. 1989). Mistletoes develop and tolerate a more negative water potential than their hosts and due to this maintain a high transpiration flux that provides a continuous flow of photosynthate-rich phloem sap from hosts. Moreover, their succulent leaves enhance water storage and allow mistletoes to rehydrate before their hosts (Glatzel \& Geils 2009).

We did not observe consistent and large differences in fir leaf water potentials between the uninfected and infected branches as has also been reported for juniper trees (Ehleringer et al. 1986). Under high evaporative demand, a limited supply of water to leaves of infected branches could result in higher water stress. Over time the branch distal to the mistletoe dies whereas the branch segment proximal to the trunk remains alive and continues to supply water and nutrients to the parasite.

Few studies have compared the Fv/Fm of mistletoes and their hosts and results vary, sometimes showing higher values for hosts and other times higher for mistletoes (Lüttge et al. 1998). We found that the maximum photochemical efficiency $(\mathrm{Fv} / \mathrm{Fm})$ of the mistletoe was lower than that of the fir. It seems that the mistletoe receives considerable amounts of photosynthetic products from its host, and as a result mistletoe can afford a lower photosynthetic capacity than the host fir. Furthermore, drought had a negative effect on both the $\mathrm{Fv} / \mathrm{Fm}$ of the mistletoe and of the fir needles, as has also been reported for $A$. alba needles (Peguero-Pina et al. 2007). The optimal values of $\mathrm{Fv} / \mathrm{Fm}$ are around 0.83 for most plant species, including $A$. alba (Robakowski et al. 2004), while lower values will be recorded when a plant has been exposed to stress (Maxwell \& Johnson 2000). Our measurements showed that the range of mean $\mathrm{Fv} / \mathrm{Fm}$ in fir needles (0.66 to 0.80$)$ and in mistletoe $(0.54$ to 0.71 ) was lower than optimal, showing that both mistletoe and fir were often under photoinhibition, but mistletoe more strongly than its host.

The results showed that mistletoe increases the drought stress of the host fir trees and contributes to the observed fir decline and mortality. In Greece, the occurrence of mistletoe on fir trees used to be kept at a low level, mainly because mistletoe was considered an excellent feedstock for animals. In recent decades, the abandonment of mountain areas and traditional animal tending methods has dramatically reduced the demand for mistletoe forage ?? . Moreover, the uneven-aged management of fir forests coupled with the long rotation periods are important contributing factors to the observed high level of mistletoe infestation.

Pruning of mistletoe infected branches can be applied only on individual trees or along roadsides but is very expensive. Clear felling is an 
effective method to eradicate mistletoe from a heavily infested stand. Selective thinning of infected trees and favouring or introducing nonhost species are management options that can reduce mistletoe infestation levels and increase water availability to host trees (Plagnat 1950, Oliva \& Colinas 2010). However, trees that can be used as nutrient-rich food sources can also attract mistletoe bird dispersers and should be avoided (Roura-Pascual et al. 2012).

The results of this study should be interpreted with caution because we did not include bird behavior in our studies. Mistletoes have coevolved with their avian vectors and the possible interactions of bird behavior with many of the studied factors (elevation, aspect, tree age etc.) that affect mistletoe deserve further investigations.

\section{Acknowledgements}

This research has been co-financed by the European Union (European Social Fund - ESF) and Greek national funds through the Operational Program "Education and Lifelong Learning" of the National Strategic Reference Framework (NSRF) - Research Funding Program: ARCHIMEDES III, Investing in knowledge society through the European Social Fund. We are also grateful to two anonymous reviewers for their valuable comments.

\section{References}

Aussenac G., 2002. Ecology and ecophysiology of circumMediterranean firs in the context of climate change. Annals of Forest Science 59: 823-832. DOI: 10.1051/forest:2002080

Barbu C., 2009. Impact of mistletoe attack (Viscum album ssp. abietis) on the radial growth of silver fir. A case study in the North of Eastern Carpathians. Annals of Forest Research 52: 89-96.

Barbu C., 2010. The incidence and distribution of white mistletoe (Viscum album ssp. abietis) on Silver fir ( $A b$ ies alba Mill.) stands from Eastern Carpathians. Annals of Forest Research 53: 27-36.

Barbu C., 2012. Impact of white mistletoe (Viscum album ssp. abietis) infection on needles and crown morphology of silver fir (Abies alba Mill.). Notulae Botanicae Horti Agrobotanici Cluj-Napoca 40: 152-158.

Calder M., Bernhardt P., 1983. The biology of mistletoes. Academic Press, Sydney.

Catal Y., Carus S., 2011. Effect of pine mistletoe on radial growth of Crimean pine (Pinus nigra) in Turkey. Journal of Environmental Biology 32: 263-270.

Davidson N.J., True K.C., Pate J.S., 1989. Water relations of the parasite: host relationship between the mistletoe Amyema linophyllum (Fenzl) Tieghem and Casuarina obesa Miq. Oecologia 80: 321-330. DOI: 10.1007/ BF00379033.

Diminić D., Potočić N., Jazbec A., Županić M., 2011. Infestation of common mistletoe and nutrition status of silver fir in gorski Kotar (Croatia). Croatian Journal of Forest Engineering 32: 223-237.

Dobbertin M., Rigling A., 2006. Pine mistletoe (Viscum album ssp. austriacum) contributes to Scots pine (Pinus sylvestris) mortality in the Rhone valley of Switzerland. Forest Pathology 36: 309-322. DOI: 10.1111/j.14390329.2006.00457.x.

Economou A., Michopoulos P., Voulala M., Bourletsikas A., 2007. Defoliation of fir on an intensively monitored plot in central Greece. Fresenius Environmental Bulletin 16: 770-775.

Ehleringer J.R., Cook C.S., Tieszen L.L., 1986. Comparative water use and nitrogen relationships in a mistletoe and its host. Oecologia 68:279-284. DOI: 10.1007/ BF00384800.

Eichhorn J., Roskams P., Ferretti M., Mues V., Szepesi A., Durrant D., 2010. Visual Assessment of Crown Condition and Damaging Agents. 49 pp. Manual Part IV. In: Manual on methods and criteria for harmonized sampling, assessment, monitoring and analysis of the effects of air pollution on forests. UNECE ICP Forests Programme Co-ordinating Centre, Hamburg.

Escher P., Peuke A.D., Bannister P., Fink S., Hartung W., Jiang F., Rennenberg H., 2008. Transpiration, CO2 assimilation, WUE, and stomatal aperture in leaves of Viscum album (L.): effect of abscisic acid (ABA) in the xylem sap of its host (Populus $x$ euamericana). Plant Physiology and Biochemistry 46:64-70. DOI: 10.1016/ j.plaphy. 2007.07.018.

Geils B.W., Hawksworth F.G., 2002. Damage, effects, and importance of dwarf mistletoes. In: Geils, B. W., Tovar, J., Moody, B. (eds.), Mistletoes of North America conifers. U.S. Dep. Agric. For. Serv. Gen. Tech. Rep. RMRS-GTR-98, pp. 57-65.

Glatzel G., 1983. Mineral nutrition and water relations of hemiparasitic mistletoes: a question of partitioning. Experiments with Loranthus europaeus on Quercus petraea and Quercus robur. Oecologia 56: 193-201. DOI: 10.1007/BF00379691

Glatzel G., Geils B.W., 2009. Mistletoe ecophysiology: host-parasite interactions. Botany 87: 10-15. DOI: 10.1139/B08-096.

Goldstein G., Rada F., Sternberg L., Burguera J.L., Bur- 
guera M., Orozco A., Montilla M., Zabala O., Azocar A., Canales M.J., Celis A., 1989. Gas exchange and water balance of a mistletoe species and its mangrove hosts. Oecologia 78:176-183. DOI: 10.1007/BF00377153.

Heliotis F.D., Karandinos M.G., Whiton J.C., 1988. Air pollution and the decline of the fir forest in Parnis National Park, near Athens, Greece. Environmental Pollution 54: 29-40. DOI: 10.1016/0269-7491(88) 90173$\mathrm{X}$.

Idžojtić M., Pernar R., Glavaš M., Zebec M., Diminić D., 2008. The incidence of mistletoe (Viscum album ssp. abietis) on silver fir (Abies alba) in Croatia. Biologia 63:81-85. DOI: 10.2478/s11756-008-0014-2.

Lüttge U., Haridasan M., Fernandes G.W., de Mattos E.A., Trimborn P., Franco A.C., Caldas L.S., Ziegler H., 1998. Photosynthesis of mistletoes in relation to their hosts at various sites in tropical Brazil. Trees 12: 167-174. DOI: 10.1007/s004680050136.

Mathiasen R.L., Nickrent D.L., Shaw D.C., Watson D.M., 2008. Mistletoes: pathology, systematics, ecology, and management. Plant Disease 92: 988-1006. DOI: 10.1094/PDIS-92-7-0988.

Maxwell K., Johnson G.N., 2000. Chlorophyll fluorescence-a practical guide. Journal of Experimental Botany 51: 659-668. DOI: 10.1093/ jexbot/51.345.659.

Muller E., Stierlin R., 1990. Tree crown photos (with percentages of foliage loss). Swiss Federal Institute for Forest, Snow and Landscape Research, $2^{\text {nd }}$ edition, 229 p.

Noetzli K.P., Muller B., Sieber T.N., 2003. Impact of population dynamics of white mistletoe (Viscum album ssp. abietis) on European silver fir (Abies alba). Annals of Forest Science 60: 773-779. DOI: 10. 1051/forest:2003072.

Oliva J., Colinas C., 2007. Decline of silver fir (Abies alba Mill.) stands in the Spanish Pyrenees: Role of management, historic dynamics and pathogens. Forest Ecology and Management 252: 84-97. DOI: 10. 1016/ j.foreco.2007.06.017.

Oliva J., Colinas C., 2010. Epidemiology of Heterobasidion abietinum and Viscum album on silver fir (Abies alba) stands of the Pyrenees. Forest Pathology 40:1932. DOI: 10.1111/j.1439-0329.2009.00603.x.

Peguero-Pina J.J., Camarero J.J., Abadía A., Martín E., González-Cascón R., Morales F., Gil-Pelegrín E., 2007. Physiological performance of silver-fir (Abies alba Mill.) populations under contrasting climates near the south-western distribution limit of the species. Flora 202: 226-236. DOI: 10.1016/j.flora.2006.06.004.

Plagnat F., 1950. Silviculture in fir stands infested with mistletoe. Revue Forestiere Francaise 7/8: 365-78. DOI: $10.4267 / 2042 / 27693$.

Popp M., Richter A., 1998. Ecophysiology of xylem-tapping mistletoes. Progress in Botany 59: 659-674. DOI: 10.1007/978-3-642-80446-5 22.

Raftoyannis Y., Radoglou K., 2001. Crown condition of a fir forest in Karpenisi, Central Greece. In: Radoglou K. (ed.). Proceedings of the International Conference "Forest Research: A challenge for an integrated European approach". Thessaloniki, Greece. pp. 317-320.

Raftoyannis Y., Spanos I., Radoglou K., 2008. The decline of Greek fir (Abies cephalonica Loudon): Relationships with root condition. Plant Biosystems 142: 386-390. DOI: $10.1080 / 11263500802151017$.

Rebetez M., Dobbertin M., 2004. Climate change may already threaten Scots pine stands in the Swiss Alps. Theoretical and Applied Climatology 79: 1-9. DOI: 10.1007/s00704-004-0058-3.

Rigling A., Eilmann B., Koechli R., Dobbertin M., 2010. Mistletoe-induced crown degradation in Scots pine in a xeric environment. Tree Physiology 30: 845-852. DOI: 10.1093/treephys/tpq038.

Robakowski P., Wyka T., Samardakiewicz S., Kierzkowski D., 2004. Growth, photosynthesis, and needle structure of silver fir (Abies alba Mill.) seedlings under different canopies. Forest Ecology and Management 201: 211227. DOI: 10.1016/j.foreco.2004.06.029.

Roura-Pascual N., Brotons L., García D., Zamora R., de Càceres M., 2012. Local and landscape-scale biotic correlates of mistletoe distribution in Mediterraean pine forests. Forest Systems 21: 179-188. DOI: 10.5424/ fs/2012212-02155.

Sangüesa-Barreda G., Linares J.C., Camarero J.J., 2012. Mistletoe effects on Scots pine decline following drought events: Insights from within-tree spatial patterns, growth and carbohydrates. Tree Physiology 32: 585-598. DOI: 10.1093/treephys/tps031.

Sangüesa-Barreda G., Linares J.C., Camarero J.J., 2013. Drought and mistletoe reduce growth and water-use efficiency of Scots pine. Forest Ecology and Management 296: 64-73. DOI: 10.1016/j.foreco.2013. 01.028.

Strong G.L., Bannister P., Burritt D., 2000. Are mistletoes shade plants? $\mathrm{CO} 2$ assimilation and chlorophyll fluorescence of temperate mistletoes and their hosts. Annals of Botany 85: 511-519. DOI: 10.1006/anbo.1999.1098.

Tsopelas P., Angelopoulos A., Economou A., Voulala M., Xanthopoulou E., 2001. Monitoring crown defoliation and tree mortality in the fir forest of Mount Parnis, Greece. International Conference on Forest Research, "A challenge for an integrated European approach"; 2001 Aug 27-Sep 1. Thessaloniki. Greece. NAGREF, Forest Research Institute, pp. 253-258.

Tsopelas P., Angelopoulos A., Economou A., Soulioti N., 2004. Mistletoe (Viscum album) in the fir forest of Mount Parnis, Greece. Forest Ecology and Management 202: 59-65. DOI: 10.1016/j.foreco. 2004.06.032

Zuber D., 2004. Biological flora of Central Europe: Viscum album L. Flora 199: 181-203. DOI: 10.1078/03672530-00147.

Zweifel R., Bangerter S., Rigling A., Sterck F.J., 2012. Pine and mistletoes: How to live with a leak in the water flow and storage system? Journal of Experimental Botany 63: 2565-2578. DOI: 10.1093/jxb/err432. 
